\title{
Comparative Assessment of Melatonin-Afforded Protection in Liver, Kidney and Heart of Male Mice against Doxorubicin Induced Toxicity
}

\author{
Abdullah A. Alghasham \\ Department of Pharmacology and Therapeutics, College of Medicine, Qassim University, Qassim, KSA. \\ Email: ghasham@qumed.edu.sa \\ Received September $10^{\text {th }}, 2013$; revised October $15^{\text {th }}, 2013$; accepted October $28^{\text {th }}, 2013$ \\ Copyright (C) 2013 Abdullah A. Alghasham. This is an open access article distributed under the Creative Commons Attribution Li- \\ cense, which permits unrestricted use, distribution, and reproduction in any medium, provided the original work is properly cited.
}

\begin{abstract}
Melatonin (MEL) was investigated for protection against the anthracycline antibiotic doxorubicin (Dox) that is well known for its oxidative damage to various body organs. It was aimed to have a comparison of this protection to heart, liver and kidney in the treated subjects. In this study, groups of mice were treated with Dox and melatonin and their individual or combined effects were evaluated by assessing lipidperoxidation, non-protein sulfhydryls (NP-SH) and nitrate/nitrite (NO) contents in these tissues. Plasma aminotransferases, LDH and CK-MB enzyme activities were measured. Moreover, these tissues were subject to histopathological assessment. MEL co-treatment significantly prevented any rise in lipidperoxides more significantly in heart and liver as compared to kidney. In tandem, MEL prevented a decline in GSH that was observed by Dox alone in liver and kidney. Dox significantly increased total NO levels in all the tissues. Melatonin at both dose levels could not afford protection against nitrosative stress. MEL in combination treatment provided significant $(\mathrm{P}<0.01)$ decline in $\mathrm{CK}-\mathrm{MB}$ at both the doses and only $5 \mathrm{mg} / \mathrm{kg}$ dose significantly prevented a rise in LDH activity and prevented any histopathological change. Melatonin, probably by behaving as an antioxidant prevented Dox-induced lipidperoxidation in heart, liver and kidney tissues and a decline in NP-SH. However, administration of MEL is able to decrease parameters of oxidative, and nitrosative stress in heart and liver more effectively than kidney.
\end{abstract}

Keywords: Melatonin; Doxorubicin; Heart; Liver; Kidney; Lipidperoxidation; Non-Protein Sulfhydryls; Nitric Oxide; Plasma Enzymes; Mice

\section{Introduction}

Doxorubicin (Dox), an anthracycline antibiotic, is primarily used in the treatment of a variety of pathological states including breast cancer, small cell carcinoma of lung, and acute leukemia [1]. The clinical usage of this agent is restricted due to its toxic manifestations to heart [2], liver and kidney [3,4] which are attributed to its redox activation to a semiquinone intermediate resulting in generation of superoxide radicals $[5,6]$. Consequently, there is immense interest in escalating the clinical usefulness of Dox by developing new adjuncts that could result in diminution of its toxicity. Hence, the administration of a variety of antioxidants with Dox has been reported. N-acetylcysteine [7], desferrioxamine [8], probucol [9], captopril [10,11], and thymoquinone [12,13] have all been shown to reduce Dox induced cardiotoxic- ity in experimental models. The reported mechanisms by which these cardiotoxic effects are manifested include alteration in sarcolemmal calcium transport [14], and lipid peroxidation [15] mediated via the formation of free radicals [16-18]. Tissues with less developed antioxidant defense mechanisms, especially the heart, are therefore highly susceptible to injury that is induced by free radical generation [19]. An increasing evidence indicates that NO mediates a plethora of actions through cGMC-independent mechanisms [20-24]. Nitric oxide ( $\left.\mathrm{NO}^{\circ}\right)$, which is synthesized by a family of nitric oxide synthase (NOS) and all of them have been localized in the kidney [25] may lead to production of reactive nitrogen species (RNS), such as peroxynitrite $\left(\mathrm{ONOO}^{-}\right)$, peroxynitrous acid, nitryl chloride $\left(\mathrm{NO}_{2} \mathrm{Cl}\right)$ and nitrogen dioxide radical $\left(\mathrm{NO}_{2}^{-}\right)$[26] resulting in nitrosative stress. A target for 
NO is sulfhydryl groups on proteins, to form S-nitrosothiol (SNOs) compounds. Reasonable levels of sulfhydryls are thought to be more relevant in offering protection against free radical production during treatment with Dox.

Melatonin a main hormone of pineal gland is implicated in a variety of physiological processes. Regulation of endocrine rhythms [27], antigonadotropic effects [28], neuroprotective effects, and stimulation of the immune function [29] have been reported to be affected by melatonin. The reports on its in vitro effects have shown that melatonin functions as an antioxidant, i.e. a scavenger of the hydroxy radical and peroxy radical [30,31]. It has also been shown that melatonin affords substantial protection against the oxidative destruction of lipids. Another study [32] has demonstrated that melatonin dose dependently attenuated the increase in both ROS and lipid peroxidation by acetaminophen.

Based on the rationale that melatonin functions as an antioxidant and scavenge hydroxy and peroxy radicals $[30,31]$ the experiments were designed to explore melatonin in vivo using biochemical parameters like lipidperoxides, glutathione, and nitric oxide levels as indicators of free radical status in the heart, liver and kidney tissues of mice treated with doxorubicin (adriamycin) known to be a free radical producing drug. Similarly, plasma aminotransferases as appraise of hepatic damage, $\mathrm{LDH}$ as a measure of kidney function and CK-MB, cardiac marker, enzyme activities were measured. Furthermore, histopathological assessment of these tissues was performed to find possible evidence. Relative protection offered by melatonin to these organs was also assessed.

\section{Material and Methods}

\subsection{Animals}

Experimental design and use of animals were approved by a local ethical committee (Experimental animal handling, care and use committee of College of Medicine, Qassim University, Qassim, Saudi Arabia). Male Swiss albino (SWR) mice, weighing 25 - $30 \mathrm{~g}$ were used. The animals were housed in groups and were kept at controlled temperature $\left(22^{\circ} \mathrm{C} \pm 1{ }^{\circ} \mathrm{C}\right)$, relative humidity $(50 \%)$ and light cycle $(7: 0 \mathrm{am}-7: 0 \mathrm{pm})$. Food and water were made freely accessible.

\subsection{Drugs and Chemicals}

Doxorubicin (Dox; adriamycin) was obtained from Farmitalia (Milan, Italy). Thiobarbituric acid (TBA) was a product of Fluka (Buchs, Switzerland). For determination of nitrates and nitrites, N-(1-Naphthyl)-ethylenediamine dihydrochloride (NEDD), sulfanilamide (SULF), vanadium(III) chloride $\left(\mathrm{VCl}_{3}\right)$ were all purchased from
Sigma-Aldrich. Solid $\mathrm{VCl}_{3}$ was stored in the dark under vacuum. All other chemicals and reagents used in this study were of analytical reagent grade procured from commercial sources.

In all experiments Dox was injected intraperitoneally (i.p.) $30 \mathrm{~min}$ after melatonin. Two dose levels for melatonin were tested in vivo. The sacrifice timing of the treatment groups was kept at 6 hours after the last dosage. The reason for selecting this time point was our preliminary work where maximal response of melatonin was found to be between $5-6$ hours of the treatment with the same dose regimen by i.p. route. A total of 72 mice were randomly assigned to 2 sets. One set of six experimental groups of mice was treated as follows: 1) vehicle control (Saline); 2) doxorubicin $2.5 \mathrm{mg} / \mathrm{kg} / \mathrm{day}$, for consecutive five days [33]; 3) melatonin $1 \mathrm{mg} / \mathrm{kg}$, for consecutive five days; 4) melatonin $1 \mathrm{mg} / \mathrm{kg}$, for consecutive five days followed by doxorubicin $2.5 \mathrm{mg} / \mathrm{kg} /$ day; 5) melatonin $5 \mathrm{mg} / \mathrm{kg}$, for consecutive five days; 6) melatonin 5 $\mathrm{mg} / \mathrm{kg}$, for consecutive five days followed by doxorubi$\operatorname{cin} 2.5 \mathrm{mg} / \mathrm{kg} / \mathrm{day}$.

Six hours after the last dosage, animals from each group were killed by cervical dislocation. In the first set, abdomen was incised and the liver, kidney and heart tissues from each group were excised of the body. A part of freshly isolated tissue was cut and used for the analysis of glutathione contents. The other part of these tissues were immediately frozen by using HistoFreeze ${ }^{\mathrm{TM}}$ (Fisher Scientific Company, Pittsburgh, PA, USA) and kept at $-40^{\circ} \mathrm{C}$ until used for the determination of lipid peroxides or NO as a measure for the level of free radicals. From the second set of treatment groups, blood was collected under light ether anesthesia and plasma was isolated to use in assessment of enzyme activities. These animals were then killed by cervical dislocation and their liver, kidney and heart tissues were preserved in buffered formalin and used in histological studies after processing.

\subsection{Estimation of Lipid Peroxides}

The method described by Ohkawa et al., [34] was used with some modifications. Malondialdehyde (MDA) was measured as an indicator of lipidperoxidation. Liver, heart or kidney tissues were thawed and homogenized in aqueous $\mathrm{KCl}$ solution, supplemented with $0.5 \%$ butylated hydroxytoluene, by using Ultra-Turrax ${ }^{\circledR}$ (Janke and Kunkel GmbH \& Co. KG IKA-WERK Staufen) homogenizer at $20 \times 1000 \mathrm{rpm}$ for few seconds. The aliquots of tissue homogenate were immediately treated with $20 \%$ acetic acid (pH 3.5) and sodium dodecyl sulphate was added. The whole mixture was incubated with thiobarbituric acid ( $0.8 \%$ aqueous) for one hour at $95^{\circ} \mathrm{C}$ using ball condensers and cooled to room temperature. After centrifugation the pink clear layer was extracted and read on 
a spectrophotometer against reagent blank. Malondialdehyde bis (dimethyl acetal) tetra ammonium salt was used as an external standard.

\subsection{Estimation of Non-Protein Sulfhydryl Groups (NP-SH)}

The tissue levels of the acid soluble thiols, mainly reduced glutathione (GSH) in liver, heart or kidney tissue were measured as described by Sedlak and Lindsay [35]. The fresh tissues were immediately homogenized in ice cold $0.02 \mathrm{M}$ ethylenediaminetetraacetic acid disodium. Aliquots of tissue homogenate were treated with $50 \%$ w/v trichloroacetic acid while shaking, kept for $15 \mathrm{~min}$ and centrifuged. Supernatant fractions were mixed with Tris buffer $\mathrm{pH}$ 8.9; 5-5'-dithiobis-(2-nitrobenzoic acid) (DTNB) was added. After mixing the contents, samples were colorimetrically read at $412 \mathrm{~nm}$ within $5 \mathrm{~min}$ of the addition of DTNB against reagent blank with no homogenate. Reduced glutathione was used as an external standard.

\subsection{Determination of Total Nitrate and Nitrite (NO)}

The level of NO in tissues was determined in the form of total nitrate and nitrite the stable main metabolite of NO. A colorimetric method adopted from Miranda et al. [36] was used. The procedure started with deproteinization of $300 \mu \mathrm{l}$ of tissue homogenate by the addition of an equal amount of methanol. The mixture was shaken and set aside in refrigerator till protein sedimentation. Then the tubes were centrifuged at $3000 \mathrm{rpm}$ for $10-15 \mathrm{~min}$. An aliquot of $300 \mu \mathrm{l}$ of the clear supernatant was then aspirated and mixed with an equal volume of $\mathrm{VCl}_{3}$ followed by another $300 \mu \mathrm{l}$ of a mixture containing equal amounts of sulfanilic acid (SULF) and N-(1-Naphthyl)-ethylenediamine (NEDD) premixed just prior to the assay. Reagent blank was the same but using $300 \mu$ of distilled water in place of sample. Absorbance was measured at $540 \mathrm{~nm}$ using a spectrophotometer (UV1201; Schimadzu Corporation, Japan) after $30-45 \mathrm{~min}$ incubation at $37^{\circ} \mathrm{C}$.

Kits for enzymes activities of glutamic-oxaloacetic transaminase (AST, EC 2.6.1.1), glutamic-pyruvic transaminase (ALT, EC 2.6.1.2), lactate dehydrogenase (LDH, EC 1.1.1.27) from United Diagnostic Industry, Dammam Saudi Arabia were used. Kits for the determination of CK-MB were procured from Boehringer Mannheim, $\mathrm{GmbH}$, Mannheim, Germany.

\subsection{Histopathological Procedure}

Tissue from the liver, heart and kidney was excised from each group and fixed in neutral buffered formalin solution for $24 \mathrm{~h}$. After fixation, each sample was dehydrated, cleared and embedded in paraffin wax. Sections of about $5 \mu \mathrm{m}$ thickness were cut with an American optical rotary microtome. These sections were stained with Harris' hematoxylin and counter stained with eosin, using the routine procedure [37]. The slides were examined under the microscope for pathomorphological changes such as necrosis, degeneration, vacuolization, inflammation, parenchymal cell death, distortion, collagen formation, alteration in cell size, presence of nuclei, presence of Kupffer cells, regeneration and severity of histopathological state.

\section{Statistical Analysis}

GraphPad InStat ${ }^{\circledR} 3.10$, version 1.3.2 was employed for statistical inference. Data are expressed as mean \pm SEM. The one-way analysis of variance (ANOVA) followed by Tukey-Kramer multiple comparisons is used to analyze the data. $\mathrm{P}<0.05$ is considered to be statistically significant.

\section{Results}

\subsection{Effect of Melatonin on Tissue Lipidperoxides}

Dox increased lipidperoxide contents significantly $(\mathrm{P}<$ 0.001) in heart, liver and kidney tissues when used alone in mice for consecutive five days. Treatment with melatonin was not different from control group. Co-treatment with melatonin in combination groups prevented rise in levels of lipid peroxides significantly at $5 \mathrm{mg} / \mathrm{kg}$ dose. This protection was more pronounced in heart and liver tissue being significant at $\mathrm{P}<0.001$. Whereas, protection afforded by melatonin was significant at $\mathrm{P}<0.05$ in the kidney tissue (Table 1).

\subsection{Effect of Melatonin on Tissue Non-Protein Sulfhydryl Contents}

Dox treatment for five days declined NP-SH contents significantly $(\mathrm{P}<0.001)$ in all the three tissues analyzed. On the other hand GSH levels remained essentially at base levels close to the control group in heart, liver and kidney tissues after treatment with melatonin. Similarly, melatonin at $1 \mathrm{mg} / \mathrm{kg}$ dose failed to prevent any change in GSH contents that were significantly reduced by Dox. Melatonin co-treatment at $5 \mathrm{mg} / \mathrm{kg}$ dose level protected heart and liver tissue significantly $(\mathrm{P}<0.001)$. The prevention in GSH decline was not significant in kidney tissue at both of the doses of melatonin (Table 2).

\subsection{Effect of Melatonin on Serum Nitrite and Nitrates (NO)}

Dox treatment for consecutive five days increased NO 
Table 1. Effect of melatonin on lipid peroxidation (nmol/g wet tissue) induced by doxorubicin in liver, kidney and heart tissue of mice.

\begin{tabular}{ccccc}
\hline Group & Treatment & Heart & Kidney & Liver \\
\hline 1 & Vehicle control & $267.8 \pm 6.25$ & $212.55 \pm 5.84$ & $268.45 \pm 7.51$ \\
2 & Doxorubicin & $403.42 \pm 7.21^{* * *}$ & $326.05 \pm 8.68^{* * *}$ & $392.18 \pm 8.06^{* * *}$ \\
3 & Melatonin $1 \mathrm{mg} / \mathrm{kg}$ & $296.18 \pm 8.25^{\sharp}$ & $210.75 \pm 9.12^{\#}$ & $272.16 \pm 6.99^{\#}$ \\
4 & Melatonin $1 \mathrm{mg} / \mathrm{kg},+$ doxorubicin & $400.10 \pm 6.46^{* * *}$ & $320.11 \pm 8.70^{* * *}$ & $378.90 \pm 7.12^{* * *}$ \\
5 & Melatonin $5 \mathrm{mg} / \mathrm{kg}$ & $301.30 \pm 7.75^{* \#}$ & $231.21 \pm 11.45^{\#}$ & $288.60 \pm 8.18^{\$}$ \\
6 & Melatonin $5 \mathrm{mg} / \mathrm{kg}+$ doxorubicin & $321.18 \pm 8.12^{* * * *}$ & $255.64 \pm 7.72^{* \#}$ & $348.45 \pm 7.95^{* * * *}$ \\
\hline
\end{tabular}

Six animals were used in each treatment group. Values are expressed as Mean \pm SEM. Treatments were given daily for consecutive five days. Statistical analysis was done by One Way ANOVA followed by Tukey-Kramer multiple comparisons test in each column independently. All the groups were compared to control. ${ }^{*} \mathrm{P}<0.05 ;{ }^{* *} \mathrm{P}<0.01$ and ${ }^{* * *} \mathrm{P}<0.001 .{ }^{*} \mathrm{P}<0.001$ and ${ }^{\$} \mathrm{P}<0.01$ compared to doxorubicin alone; ${ }^{\circledR} \mathrm{P}<0.001$ Group 6 compared to Group 4.

Table 2. Effect of melatonin and doxorubicin on non-protein sulfhydryl contents (nmol/100mg wet tissue) in liver, kidney and heart tissue in mice.

\begin{tabular}{ccccc}
\hline Group & Treatment & Heart & Kidney & Liver \\
\hline 1 & Vehicle control & $56.45 \pm 3.11$ & $42.45 \pm 2.49$ & $66.32 \pm 3.16$ \\
2 & Doxorubicin & $28.42 \pm 2.57^{* * *}$ & $31.40 \pm 2.69$ & $43.18 \pm 2.91^{* * *}$ \\
3 & Melatonin $1 \mathrm{mg} / \mathrm{kg}$ & $53.10 \pm 2.61^{* * *}$ & $44.10 \pm 3.15^{\Delta}$ & $64.26 \pm 2.90^{\sharp}$ \\
4 & Melatonin $1 \mathrm{mg} / \mathrm{kg},+$ doxorubicin & $30.45 \pm 2.78$ & $32.70 \pm 2.91$ & $55.92 \pm 2.78^{\Delta}$ \\
5 & Melatonin $5 \mathrm{mg} / \mathrm{kg}$ & $52.15 \pm 2.70^{\#}$ & $40.01 \pm 2.33$ & $61.11 \pm 3.12^{\$}$ \\
6 & Melatonin $5 \mathrm{mg} / \mathrm{kg}+$ doxorubicin & $41.49 \pm 2.85^{* * \Delta}$ & $37.55 \pm 2.15$ & $48.44 \pm 2.70^{* *}$ \\
\hline
\end{tabular}

Six animals were used in each treatment group. Values are expressed as Mean \pm SEM. Treatments were given daily for consecutive five days. Statistical analysis was done by One Way ANOVA followed by Tukey-Kramer multiple comparisons test in each column independently. All the groups were compared to control. ${ }^{*} \mathrm{P}<0.05 ;{ }^{* *} \mathrm{P}<0.01$ and ${ }^{* * *} \mathrm{P}<0.001 .{ }^{*} \mathrm{P}<0.001,{ }^{S} \mathrm{P}<0.01$ and ${ }^{\Delta} \mathrm{P}<0.05$ compared to doxorubicin alone; ${ }^{\circledR} \mathrm{P}<0.001$ Group 6 compared to Group 4 .

levels significantly $(\mathrm{P}<0.001$ in heart and liver and $\mathrm{P}<$ 0.01 in kidney tissue). Melatonin at $1 \mathrm{mg} / \mathrm{kg}$ dose could not afford protection against Dox in combination treatment and NOlevels remained close to Dox alone. However, melatonin $5 \mathrm{mg} / \mathrm{kg}$ prevented rise in NO contents but was not significantly low and did not reach to control group in any of the tissues analyzed (Table 3).

\subsection{Effect of Melatonin on Plasma Biochemical Parameters}

Melatonin alone did not have any significant effect on plasma enzyme activities at both dose levels. Dox treatment for consecutive five days significantly elevated aminotransferases, LDH and CK-MB. In the combined treatment groups, melatonin treatment significantly prevented any rise in CK-MB activities at both the dose levels. Melatonin at $5 \mathrm{mg} / \mathrm{kg}$ was found to decrease LDH activities significantly $(\mathrm{P}<0.05)$. However, both the doses of melatonin failed to avert any rise in activities of aminotransferases in plasma of Dox treated groups (Table 4).

\subsection{Effect of Melatonin on Doxorubicin Induced Histological Changes}

Low dose of melatonin in combination with Dox has shown mild symptoms of fine granulated and eosinic cytoplasm with leucocytic infiltration and hyperchromacia in the cardiac tissue of mice. This shows a relative failure of melatonin $1 \mathrm{mg} / \mathrm{kg}$ dose to prevent any change in the heart tissue histological features (Figure 1). Similarly the kidneys from the same treatment group showed degenerative changes marked as cloudy swelling, tubular cell necrosis and sloughing in the tubular lumens (Figure 2). Hepatocytic vacuolation with mononuclear inflammatory cell infiltration was noticed in this treatment group (Figure 3). Co-treatment with melatonin $5 \mathrm{mg} / \mathrm{kg}$ and Dox demonstrated significant protection to the cardiac tissue that appeared almost normal in its architecture with few myocardial cells showing hypertrophy. Slides of kidney tissue from this group appeared normal in the architecture except interstitial edema with mononuclear cell infiltration. Liver tissue in this group appeared normal except few hepatocytes typify atrophied.

\section{Discussion}

A number of research reports indicate that melatonin effectively attenuated Dox-induced cardiotoxicity [38], nephrotoxicity [39] and hepatotoxicity [40] in experimental models. It was suggested that melatonin has antioxidant potential [41] and might play an important role in the attenuation of free radical induced toxicity to heart, 
Table 3. Effect of Melatonin pretreatment on NO contents ( $\mu \mathrm{mol} / \mathrm{g}$ wet tissue) in heart, kidney and liver tissue of mice treated with doxorubicin.

\begin{tabular}{|c|c|c|c|c|}
\hline Group & Treatment & Heart & Kidney & Liver \\
\hline 1 & Vehicle control & $406 \pm 41$ & $724 \pm 63$ & $644 \pm 41$ \\
\hline 2 & Doxorubicin & $705 \pm 53^{* * *}$ & $1044 \pm 64^{* *}$ & $898 \pm 38^{* * *}$ \\
\hline 3 & Melatonin $1 \mathrm{mg} / \mathrm{kg}$ & $422 \pm 47^{\$}$ & $740 \pm 55^{\$}$ & $656 \pm 42^{\$}$ \\
\hline 4 & Melatonin $1 \mathrm{mg} / \mathrm{kg}$, +doxorubicin & $742 \pm 48^{* * *}$ & $1048 \pm 61^{* *}$ & $848 \pm 31^{* * *}$ \\
\hline 5 & Melatonin $5 \mathrm{mg} / \mathrm{kg}$ & $428 \pm 42^{\$}$ & $742 \pm 49^{\$}$ & $658 \pm 36^{\S}$ \\
\hline 6 & Melatonin $5 \mathrm{mg} / \mathrm{kg}+$ doxorubicin & $541 \pm 41^{@}$ & $868 \pm 49$ & $695 \pm 39$ \\
\hline
\end{tabular}

Six animals were used in each treatment group. Values are expressed as Mean \pm SEM. Treatments were given daily for consecutive five days. Statistical analysis was done by One Way ANOVA followed by Tukey-Kramer multiple comparisons test in each column independently. All the groups were compared to control. ${ }^{*} \mathrm{P}<0.05 ;{ }^{* *} \mathrm{P}<0.01$ and ${ }^{* * *} \mathrm{P}<0.001$. ${ }^{*} \mathrm{P}<0.001,{ }^{S} \mathrm{P}<0.01$ and ${ }^{\Delta} \mathrm{P}<0.05$ compared to doxorubicin alone; ${ }^{\circledR} \mathrm{P}<0.05$ Group 6 compared to Group 4.

Table 4. Effect of melatonin and doxorubicin on plasma biochemical parameters (U/L, Mean \pm SEM) in mice.

\begin{tabular}{cccccc}
\hline Group & Treatment & ALT & AST & LDH & CK-MB \\
\hline 1 & Vehicle control & $19.61 \pm 0.98$ & $14.54 \pm 1.60$ & $248.66 \pm 18.23$ & $149.65 \pm 12.44$ \\
2 & Doxorubicin & $29.36 \pm 1.95^{* *}$ & $24.20 \pm 1.21^{* *}$ & $404.5 \pm 12.45^{* * *}$ & $325.35 \pm 19.38^{* * *}$ \\
3 & Melatonin $1 \mathrm{mg} / \mathrm{kg}$ & $21.33 \pm 1.79^{\Delta}$ & $16.58 \pm 1.81^{\Delta}$ & $261.35 \pm 21.48^{\#}$ & $168.90 \pm 19.8^{\#}$ \\
4 & Melatonin 1 $\mathrm{mg} / \mathrm{kg}+$ doxorubicin & $26.48 \pm 1.98$ & $23.32 \pm 0.99^{* *}$ & $361.32 \pm 22.72^{* *}$ & $238.05 \pm 11.90^{* * \$}$ \\
5 & Melatonin 5 mg/kg & $22.03 \pm 1.69^{\Delta}$ & $17.11 \pm 1.51^{\Delta}$ & $265.76 \pm 21.70^{\#}$ & $195.55 \pm 10.69^{\#}$ \\
6 & Melatonin 5 mg/kg + doxorubicin & $23.36 \pm 1.39$ & $20.22 \pm 2.05$ & $308.95 \pm 14.14^{\Delta}$ & $239.80 \pm 4.85^{* * \$}$ \\
\hline
\end{tabular}

Six animals were used in each treatment group. Values are expressed as Mean \pm SEM. Treatments were given daily for consecutive five days. Statistical analysis was done by One Way ANOVA followed by Tukey-Kramer multiple comparisons test in each column independently. All the groups were compared to control. ${ }^{*} \mathrm{P}<0.05 ;{ }^{* *} \mathrm{P}<0.01$ and ${ }^{* * * *} \mathrm{P}<0.001 .{ }^{\#} \mathrm{P}<0.001,{ }^{\mathrm{P}} \mathrm{P}<0.01$ and ${ }^{\Delta} \mathrm{P}<0.05$ compared to doxorubicin alone; ${ }^{\circledR} \mathrm{P}<0.05$ Group 6 compared to Group 4 .

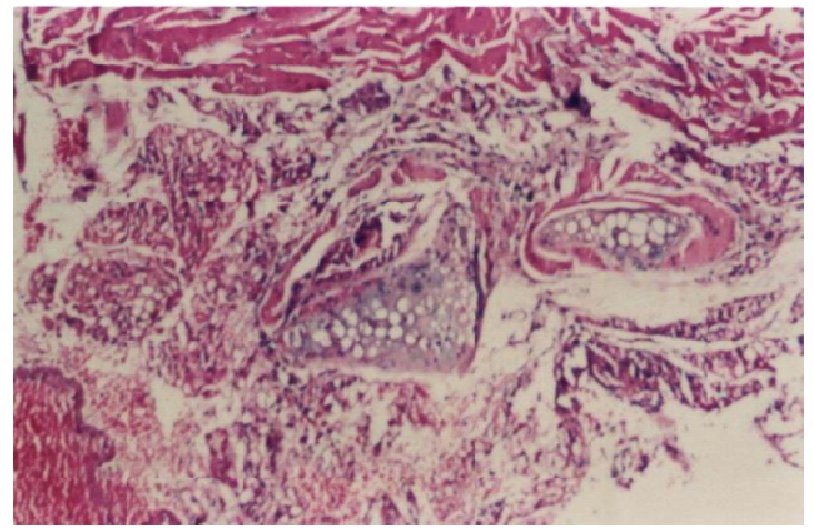

Figure 1. Micrograph showing granulated and eosinic cytoplasm, leucocytic infiltrate and hyperchromacia in cardiac tissue in melatonin $1 \mathrm{mg} / \mathrm{kg}$ and Dox treated mice $(\mathrm{H} \& \mathrm{E}$ $\times 400)$.

liver and kidney that are produced by metabolic pathways of doxorubicin. In the present study, doxorubicin treatment resulted in an increase of malondialdehyde (MDA) in all the tissues analyzed. Heart tissue was most susceptible to deleterious effects of Dox reflected by an increase in levels of MDA, NO and elevated activity of CK-MB with a concomitant decrease in the contents of NP-SH. Furthermore, histological findings paralleled the levels of MDA. Doroshow, [19] suggested that tissues with less developed antioxidant defense mechanisms,

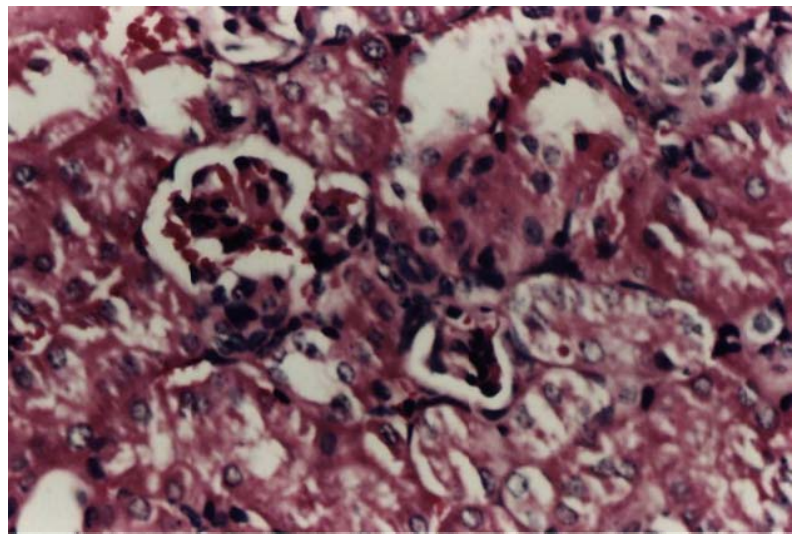

Figure 2. Micrograph showing degenerating cloudy swelling and sloughing in tubular lumens in kidney tissue in melatonin $1 \mathrm{mg} / \mathrm{kg}$ and Dox treated mice $(\mathrm{H} \& \mathrm{E} \times 400)$.

especially the heart, are therefore highly susceptible to free radical injury. In the present study melatonin effectively prevented rise in the levels of these indicators of oxidative stress in heart, liver and kidney tissues indicated by a pronounced protection to the heart tissue. This is in accordance with previous studies stating melatonin as being very potent antioxidant having potential to scavenge hydroxyl radicals [41], peroxy radicals $\left(\mathrm{ROO}^{\circ}\right)$, superoxide anions [41,42] and $\mathrm{H}_{2} \mathrm{O}_{2}$ [43]. Hardeland et al., [41] has also shown melatonin to be more potent than mannitol or glutathione in scavenging hydroxyl radical 


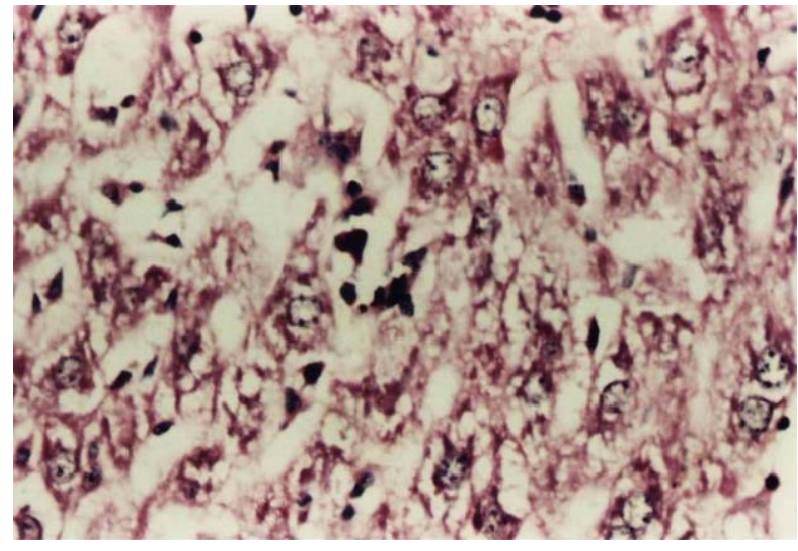

Figure 3. Micrograph showing hepatic vacuolation with mononuclear inflammatory cell infiltrate in hepatic tissue in melatonin $1 \mathrm{mg} / \mathrm{kg}$ and Dox treated mice $(\mathrm{H} \& \mathrm{E} \times 400)$.

and also, more potent than vitamin $\mathrm{E}$ in sequestering peroxyl radicals [44]. Another advantage associated with melatonin is its distribution to sub-cellular compartments because of its solubility in water as well as in lipids making it readily available to afford protection [44]. Present study strengthens the findings of Chen et al., [45] who demonstrated free radical load being a cause of myocardial infarction. In another study, Liu et al., [38] has verified melatonin protecting against Dox induced cardiotoxicity.

In the present study melatonin treatment prevented decline in the contents of sulfhydryl contents in heart, liver and kidney tissues. Hardeland et al., [41] has demonstrated that melatonin is almost five times more potent in scavenging hydroxyl radicals that might result in sparing endogenous sulfhydryls and lead to restoration of their level in all the tissues. Matsura et al., [46] has also demonstrated that treatment with melatonin did not change GSH levels in their study and as such our results are in accordance with their results. In the present study, melatonin alone did not change the sulfhydryl contents of the tissue at both doses. It is suggested that since melatonin is readily distributed in sub-cellular compartments making it available being the first line of defense against free radical load. In a recent study, Ozan et al., [39] have demonstrated melatonin in protecting free radical induced damage to kidney by cigarette smoke. They reported melatonin to cause a decrease in malondialdehyde (MDA) and GSH (glutathione) levels and avert structural changes. The results of this study are consistent with the findings of Oktem et al., [47] who demonstrated melatonin to prevent an increase in MDA levels of renal tissue and decrease in renal tissue SOD and GSH-Px activities and related it to its radical scavenging and anti-oxidant properties.

There is sufficient evidence in the literature indicating that melatonin protects liver against free radical load. Matsura et al., [46] have shown that melatonin protected against acetaminophen induced sever damage to mouse liver and suggested that exogenously administered melatonin exhibits a potent hepatoprotective effect against acetaminophen induced hepatic damage via its antinitrosative and anti-inflammatory activities in addition to its antioxidant potential. Another study showed melatonin effective in reducing MDA contents [48]. Sahna et al., [48] demonstrated a parallel relation between MDA and morphological changes in the heart tissue that was prevented by pharmacological doses of melatonin. Othman et al., [40] demonstrated that Dox induces lipidperoxidation in the liver and decreases GSH levels. They attributed this effect to the oxidative stress that was prevented by melatonin.

In the present study, Dox treatment induced the cardiac, hepatic and renal damage as it was shown by plasma biochemical markers that have indicated an increase in their activities. Concomitant administration of melatonin as an effective antioxidant demonstrated that melatonin is a cytoprotective against Dox induced free radical load. Cotreatment with melatonin replenished the depleted GSH levels back to normal and furthermore, decreased MDA to attain levels non-significantly different from normal values in parallel to regression of hepatic, cardiac and renal toxicity indicators.

Dox-induced cytoplasmic vacuolization and mitochondrial swelling was confirmed by Bellini and Solcia [10]. It has been previously established that Dox induces mitochondrial injury through generation of superoxide anions. Results of the present study suggest that the prevention of pathological changes by melatonin can be attributed at least in part to the preservation of subcellular integrity of cardiac myocytes [49].

Liu et al., [38] also reported effects of melatonin on Dox-induced cardiotoxicity and demonstrated it to be protective. In the present study low dose of melatonin failed to protect against Dox-induced toxicity. This could be attributed to the low dose of melatonin used in this study. In most of the studies referred here, bit high doses are reported. However, plasma $t^{1} / 2$ of melatonin is short (20 - $40 \mathrm{~min}$ ), but tissue levels of melatonin remain high enough than physiological levels even when plasma melatonin levels fall to the physiological levels [50].

In conclusion, melatonin, probably by behaving as an antioxidant protected mice from Dox-induced lipidperoxidation and $\mathrm{NO}$ in heart, liver and kidney tissues and prevented a decline in GSH which is a first barrier in preventing oxidative and nitrosative damage. Results, also, show that protection is more pronounced in heart and liver as compared to kidneys. Moreover, results on plasma aminotransferases, LDH and CK-MB indicated 
that melatonin declined CK-MB more effectively preventing any damage to heart. These findings support the role of free radical induced toxicity by Dox. However, administration of melatonin is able to decrease parameters of oxidative, and nitrosative stress in heart and liver more effectively than kidney.

\section{REFERENCES}

[1] R. H. Blum and S. K. Carter, "Adriamycin: A New Anticancer Drug with Significant Clinical Activity," Annals of Internal Medicine, Vol. 80, No. 2, 1974, pp. 249-259. http://dx.doi.org/10.7326/0003-4819-80-2-249

[2] P. K. Singal, C. M. R. Deally and L. E. Weinberg, "Subcellular Effects of Adriamycin in the Heart: A Concise Review," Journal of Molecular and Cellular Cardiology, Vol. 19, No. 8, 1987, pp. 817-828.

http://dx.doi.org/10.1016/S0022-2828(87)80392-9

[3] M. P. O'Donnel, L. Pichels, B. L. Kasiske, L. Raij and W. F. Keane, "Adriamycin-Induced Chronic Proteinuria: A Structural and Functional Study," Journal of Laboratory and Clinical Medicine, Vol. 106, No. 1, 1985, pp. 62-67.

[4] T. Zima, V. Tesar, J. Crkovská, A. Stejskalová, J. Pláteník, J. Temínová, K. Nemecek, M. Janebová and S. Stípek, "ICRF-187 (Dexrazoxan) Protects from Adriamycin-Induced Nephrotic Syndrome in Rats," Nephrology Dialysis Transplantation, Vol. 13, No. 8, 1998, pp. 19751979. http://dx.doi.org/10.1093/ndt/13.8.1975

[5] S. Kotamraju, E. A. Konorev, J. Joseph and B. Kalyanaraman, "Doxorubicin-Induced Apoptosis in Endothelial Cells and Cardiomyocytes Is Ameliorated by Nitrone Spin Traps and Ebselen. Role of Reactive Oxygen and Nitrogen Species," Journal of Biological Chemistry, Vol. 275, No. 43, 2000, pp. 33585-33592. http://dx.doi.org/10.1074/jbc.M003890200

[6] G. Minotti, G. Cairo and E. Monti, "Role of Iron in Anthracycline Cardiotoxicity: New Tunes for an Old Song?" FASEB Journal, Vol. 13, No. 2, 1999, pp. 199-212.

[7] J. H. Doroshow, G. Y. Looker, I. Ifrimand and C. E. Myers, "Prevention of Doxorubicin Cardiac Toxicity in the Mouse by Nacetylcysteine," Journal of Clinical Investigation, Vol. 68, No. 4, 1981, pp. 1053-1064. http://dx.doi.org/10.1172/JCI110328

[8] M. M. Al-Harbi, N. M. Al-Gharably, O. A. Al-Shabanah, A. M. Al-Bekairi, A. M. Osman and H. N. Tawfik, "Prevention of Doxorubicin-Induced Myocardial and Haematological Toxicities in Rats by the Iron Chelator Desferrioxamine," Cancer Chemotherapy and Pharmacology, Vol. 31, No. 3, 1992, pp. 200-204. http://dx.doi.org/10.1007/BF00685548

[9] P. K. Singal, N. Siveski-Iliskovic, M. Hill, T. Thomas and T. Li, "Combination Therapy with Probucol Prevents Adriamycin-Induced Cardiomyopathy," Journal of Molecular and Cellular Cardiology, Vol. 27, No. 4, 1995, pp. 1055-1063.

http://dx.doi.org/10.1016/0022-2828(95)90074-8

[10] O. Bellini and E. Solcia, "Early and Late Sarcoplasmic
Reticulum Changes in Doxorubicin Cardiomyopathy. An Ultrastructural Investigation with the Zinc Iodide-Osmium Tetroxide (ZIO) Technique," Virchows Archiv B, Vol. 49, No. 1, 1985, pp. 137-152. http://dx.doi.org/10.1007/BF02912092

[11] O. Al-Shabanah, M. Mansour, H. El-Kashef and A. AlBekair, "Captopril Ameliorates Myocardial and Hematological Toxicities Induced by Doxorubicin," Biochemistry \& Molecular Biology International, Vol. 45, No. 2, 1998, pp. 419-427.

[12] O. A. Al-Shabanah, O. A. Badary, M. N. Nagi, N. AlGarably, A. Al-Rikabi and A. M. Al-Bekairi, "Thymoquinone Protects against Doxorubicin-Induced Cardiotoxicity without Compromising Its Antitumor Activity," Journal of Experimental \& Clinical Cancer Research, Vol. 17, No. 2, 1998, pp. 193-198.

[13] M. N. Nagi and M. A. Mansour, "Protective Effect of Thymoquinone against Doxorubicin-Induced Cardiotoxicity in Rats: A Possible Mechanism of Protection," Pharmacological Research, Vol. 41, No. 3, 2000, pp. 283-289. http://dx.doi.org/10.1006/phrs.1999.0585

[14] P. K. Singal and G. N. Pierce, "Adriamycin Stimulates Low Affinity Calcium Binding and Lipid Peroxidation but Depresses Myocardial Function," American Journal of Physiology, Vol. 1250, 1986, pp. 419-425.

[15] C. E. Myers, W. P. McGuire, R. H. Liss, I. Ifirm, K. Grotzinger and R. C. Young, "Adriamycin: The Role of Lipid Peroxidation in Cardiac Toxicity and Tumor Response," Science, Vol. 19, 1997, pp. 165-167.

[16] I. Morishima, H. Matsui, H. Mukawa, K. Hayashi, Y. Toki, K. Okumura, T. Ito and T. Hayakawa, "Melatonin a Pineal Hormone with Antioxidant Property Protect against Adriamycin Cardiomyopathy in Rats," Life Science, Vol. 63, No. 7, 2000, pp. 511-521. http://dx.doi.org/10.1016/S0024-3205(98)00302-6

[17] N. Siveski-Iliskovic, N. Kaul and P. K. Singal, "Probucol Promotes Endogenous Antioxidants and Provides Protection against Adriamycin-Induced Cardiomyopathy in Rats," Circulation, Vol. 89, 1994, pp. 2829-2835. http://dx.doi.org/10.1161/01.CIR.89.6.2829

[18] M. F. Xu, P. L. Tang, Z. M. Qian and M. Ashraf, "Effects by Doxorubicin on the Myocardium Are Mediated by Oxygen Free Radicals," Life Sciences, Vol. 68, No. 8, 2001, pp. 889-901. http://dx.doi.org/10.1016/S0024-3205(00)00990-5

[19] J. H. Doroshow, "Effect of Anthracyclin Antibiotics on Oxygen Radical Formation in Rat Heart," Cancer Research, Vol. 43, No. 2, 1983, pp. 460-472.

[20] L. J. Ignarro, G. Cirino, A. Casini and C. Napoli, "Nitric Oxide as a Signaling Molecule in the Vascular System: An Overview," Journal of Cardiovascular Pharmacology, Vol. 34, No. 6, 1999, pp. 879-886.

http://dx.doi.org/10.1097/00005344-199912000-00016

[21] V. W. T. Liu and P. L. Huang, "Cardiovascular Roles of Nitric Oxide: A Review of Insights from Nitric Oxide Synthase Gene Disrupted Mice," Cardiovascular Research, Vol. 77, No. 1, 2008, pp. 19-29.

[22] C. Napoli and L. J. Ignarro, "Nitric Oxide and Athero- 
sclerosis," Nitric Oxide, Vol. 5, No. 2, 2001, pp. 88-97. http://dx.doi.org/10.1006/niox.2001.0337

[23] C. Napoli, F. de Nigris, S. Williams-Ignarro, O. Pignalosa, V. Sica and L. J. Ignarro, "Nitric Oxide and Atherosclerosis: An Update," Nitric Oxide, Vol. 15, No. 4, 2006, pp. 265-279. http://dx.doi.org/10.1016/j.niox.2006.03.011

[24] T. J. Rabelink and T. F. Luscher, "Endothelial Nitric Oxide Synthase: Host Defense Enzyme of the Endothelium?" Arteriosclerosis, Thrombosis, and Vascular Biology, Vol. 26, No. 2, 2006, pp. 267-271.

http://dx.doi.org/10.1161/01.ATV.0000196554.85799.77

[25] B. C. Kone, "Nitric Oxide Synthesis in the Kidney: Isoforms, Biosynthesis, and Functions in Health," Seminars in Nephrology, Vol. 24, No. 4, 2004, pp. 299-315. http://dx.doi.org/10.1016/j.semnephrol.2004.04.002

[26] J. W. Coddington, J. K. Hurst and S. V. Lymar, "Hydroxyl Radical Formation during Peroxynitrous Acid Decomposition," Journal of the American Chemical Society, Vol. 121, No. 11, 1999, pp. 2438-2443. http://dx.doi.org/10.1021/ja982887t

[27] M. L. Forsling, R. P. Stoughton, Y. Zhou, H. Kelestimur and C. Demaine, "The Role of the Pineal in the Control of the Daily Patterns of Neurohypophysial Hormone Secretion," Journal of Pineal Research, Vol. 14, No. 1, 1993 , pp. $45-51$.

http://dx.doi.org/10.1111/j.1600-079X.1993.tb00484.x

[28] I. Kuş, N. Akpolat, O. A. Ozen, A. Songur, A. Kavakli and M. Sarsilmaz, "Effects of Melatonin on Leydig Cells in Pinealectomized Rat: An Immunohistochemical Study," Acta Histochemica, Vol. 104, No. 1, 2002, pp. 93-97. http://dx.doi.org/10.1078/0065-1281-00618

[29] J. M. Guerrero and R. J. Reiter, "A Brief Survey of Pineal Gland-Immune System Interrelationships," Endocrine Research, Vol. 18, No. 2, 1992, pp. 91-113. http://dx.doi.org/10.1080/07435809209035401

[30] S. Cuzzocrea and R. J. Reiter, "Pharmacological Action of Melatonin in Shock, Inflammation and Ischemia/ Reperfusion Injury," European Journal of Pharmacology, Vol. 426, No. 1-2, 2001, pp. 1-10. http://dx.doi.org/10.1016/S0014-2999(01)01175-X

[31] L. Y. Zang, G. Cosma, H. Gardner and V. Vallyathan, "Scavenging of Reactive Oxygen Species by Melatonin," Biochimica et Biophysica Acta, Vol. 1425, No. 3, 1998, pp. 469-477. http://dx.doi.org/10.1016/S0304-4165(98)00099-3

[32] S. Kanno, A. Tomizawa, T. Hiura, Y. Osanai, M. Kakuta, Y. Kitajima, K. Koiwai, T. Ohtake, M. Ujibe and M. Ishikawa, "Melatonin Protects on Toxicity by Acetaminophen but Not on Pharmacological Effects in Mice," Biological \& Pharmaceutical Bulletin, Vol. 29, No. 3, 2006, pp. 472-476. http://dx.doi.org/10.1248/bpb.29.472

[33] K. Suzuki, B. Murtuza, N. Suzuki, R. T. Smolenski and M. H. Yacoub, "Intracoronary Infusion of Skeletal Myoblasts Improves Cardiac Function in Doxorubicin-Induced Heart Failure," Circulation, Vol. 104, No. 12, 2001, pp. I213-I217.

[34] H. Ohkawa, N. Ohishi and K. Yagi, "Assay for Lipid Peroxides in Animal Tissues by Thiobarbituric Acid Re- action," Analytical Biochemistry, Vol. 95, 1979, pp. 351358. http://dx.doi.org/10.1016/0003-2697(79)90738-3

[35] J. Sedlak and R. H. Lindsay, "Estimation of Total, Protein Bound and Non-Protein Sulfhydryl Groups in Tissue with Elman's Reagent," Analytical Biochemistry, Vol. 25, 1968, pp. 192-205.

http://dx.doi.org/10.1016/0003-2697(68)90092-4

[36] K. M. Miranda, M. G. Espey and D. A. Wink, “A Rapid, Simple Spectrophotometric Method for Simultaneous Detection of Nitrate and Nitrite," Nitric Oxide: Biology and Chemistry, Vol. 5, No. 1, 2001, pp. 62-71.

[37] M. M. Al-Harbi, S. Qureshi, M. Raza, M. M. Ahmed, A. B. Giangreco and A. H. Shah, "Influence of Anethole Treatment on the Tumour Induced by Ehrlich Ascites Carcinoma Cells in Paw of Swiss Albino Mice," European Journal of Cancer Prevention, Vol. 4, No. 4, 1995, pp. 307-318.

http://dx.doi.org/10.1097/00008469-199508000-00006

[38] X. Liu, Z. Chen, C. C. Chua, Y. S. Ma, G. A. Youngberg, R. Hamdy and B. H. Chua, "Melatonin as an Effective Protector against Doxorubicin-Induced Cardiotoxicity," American Journal of Physiology: Heart and Circulatory Physiology, Vol. 283, No. 1, 2002, pp. H254-H263.

[39] E. Ozan, M. F. Sonmez, S. Ozan, N. Colakoglu, S. Yilmaz and T. Kuloglu, "Effects of Melatonin and Vitamin C on Cigarette Smoke-Induced Damage in the Kidney," Toxicology and Industrial Health, Vol. 23, No. 8, 2007, pp. 479-485.

http://dx.doi.org/10.1177/0748233708089023

[40] A. I. Othman, M. A. El-Missiry, M. A. Amer and M. Arafa, "Melatonin Controls Oxidative Stress and Modulates Iron, Ferritin, and Transferrin Levels in Adriamycin Treated Rats," Life Sciences, Vol. 83, No. 15-16, 2008, pp. 563-568. http://dx.doi.org/10.1016/j.1fs.2008.08.004

[41] R. Hardeland, R. J. Reiter, B. Poeggeleer and D. X. Tan, "The Significance of the Metabolism of the Neurohormone Melatonin: Antioxidative Protection and Formation of Bioactive Substances," Neuroscience \& Biobehavioral Reviews, Vol. 17, No. 3, 1993, pp. 347-357. http://dx.doi.org/10.1016/S0149-7634(05)80016-8

[42] R. J. Reiter, D. Melchiorri, E. Sewerynek, B. Poeggeler, L. Barlow-Walden, J. Chuang, G. G. Ortiz and D. AcunaCastroviejo, a Review of the Evidence Supporting Melatonin's Role as an Antioxidant," Journal of Pineal Research, Vol. 18, No. 1, 1995, pp. 1-11. http://dx.doi.org/10.1111/j.1600-079X.1995.tb00133.x

[43] R. Schulz, M. V. Cohen, M. Behrends, J. M. Downey and G. Heusch, "Signal Transduction of Ischemic Preconditioning," Cardiovascular Research, Vol. 52, No. 2, 2001, pp. 181-198. http://dx.doi.org/10.1016/S0008-6363(01)00384-4

[44] C. Pieri, M. Marra, F. Moroni, R. Recchioni and F. Marcheselli, "Melatonin: A Peroxyl Radical Scavenger More Effective than Vitamin E," Life Science, Vol. 55, No. 15, 1994, pp. pp. PL271-PL276.

[45] Z. Chen, C. C. Chua, J. Gao, R. C. Hamdy and B. H. Chua, "Protective Effect of Melatonin on Myocardial Infarction," American Journal of Physiology: Heart and 
Circulatory Physiology, Vol. 284, No. 5, 2003, pp. H1618-H1624.

[46] T. Matsura, T. Nishida, A. Togawa, S. Horie, C. Kusumoto, S. Ohata, J. Nakada, Y. Ishibe, K. Yamada and Y. Ohta, "Mechanisms of Protection by Melatonin against Acetaminophen-Induced Liver Injury in Mice," Journal of Pineal Research, Vol. 41, No. 3, 2006, pp. 211-219. http://dx.doi.org/10.1111/j.1600-079X.2006.00356.x

[47] F. Oktem, F. Ozguner, H. Mollaoglu, A. Koyu and E. Uz, "Oxidative Damage in the Kidney Induced by $900-\mathrm{MHz}-$ Emitted Mobile Phone: Protection by Melatonin," Archives of Medical Research, Vol. 36, No. 4, 2005, pp. 350-355. http://dx.doi.org/10.1016/j.arcmed.2005.03.021

[48] E. Sahna, H. Parlakpinar, M. K. Ozer, F. Ozturk, F. Ozugurlu and A. Acet, "Melatonin Protects against Myo- cardial Doxorubicin Toxicity in Rats: Role of Physiological Concentrations," Journal of Pineal Research, Vol. 35, No. 4, 2003, pp. 257-261. http://dx.doi.org/10.1034/j.1600-079X.2003.00084.x

[49] E. Oz, D. Erbaş, H. S. Sürücü and E. Düzgün, "Prevention of Doxorubicin-Induced Cardiotoxicity by Melatonin," Molecular and Cellular Biochemistry, Vol. 282, No. 1-2, 2006, pp. 31-37. http://dx.doi.org/10.1007/s11010-006-1153-9

[50] F. Raynaud, F. Mauviard, M. Geoffriau, B. Claustrat and P. Pevet, "Plasma 6-Hydroxymelatonin, 6-Sulfatoxymelatonin and Melatonin Kinetics after Melatonin Administration to Rats," Biological Signals, Vol. 2, No. 6, 1993, pp. 358-366. http://dx.doi.org/10.1159/000109516

\author{
Abbreviations \\ MDA: Malondialdehyde; \\ NP-SH: non-protein sulfhydryls; \\ GSH: glutathione; \\ DTNB: 5-5'-dithiobis-(2 nitrobenzoid acid); \\ Dox: Doxorubicin; \\ NO: Nitric oxide.
}

